\title{
Correspondence Between Technology Options Available for Chemical Industries and the Levels of the Waste Management Hierarchy: A Case Study Approach
}

\author{
S. M. D'Sa*†, D. Patnaik*, V. Acham** and S. Jadhao** \\ *Department of Economics and Management, Birla Institute of Technology and Science, Pilani, K. K. Birla Goa Campus, \\ Zuarinagar, Sancoale, Goa-403726, India \\ **Prochem Innovatives, N2 - 408, River Residency Phase 3, Chikhali, Pune-411062, India \\ $\dagger$ Corresponding Author: Sandra D’Sa; p20130104@goa.bits-pilani.ac.in
}

Nat. Env. \& Poll. Tech.

Website: www.neptjournal.com

Received: 18-12-2020

Revised: 13-02-2021

Accepted: 24-02-2021

\section{Key Words:}

Industrial wastewater

Waste management hierarchy

Technology options

Chemical industry

\section{ABSTRACT}

The Waste Management Hierarchy is used as a guiding principle for waste management of industrial solid waste. Further, it is extended for the management of industrial liquid effluents as well. The Waste Management Hierarchy consists of the five levels namely; waste prevention, reuse, recycling, recovery, and disposal. This five-tiered Waste Management Hierarchy has been adopted by the European Union under the Waste Framework Directive as a decision-making tool. This paper explores some of the technology options known and available and categorizes them according to the five levels of the Waste Management Hierarchy. This paper presents brief case studies that highlight some benefits to those who embrace this decision-making tool.

\section{INTRODUCTION}

The Environment (Protection) Act of 1986 (last amended in 1991) has empowered the Central Government of India to authorize the prevention of environmental pollution and provide environmental solutions through various mandates. This Act encompassed the Water (Prevention and Control of Pollution) Act of 1974 which was specifically concerned with the prevention of water pollution. According to the Hazardous and Other Wastes (Management and Transboundary Movement) Rules, 2016, hazardous waste as defined in the Rules needs to be generated, handled, stored, transported, treated, and disposed of with utmost care (CPCB website). All of the above Acts and Rules have one broad objective, which is to protect the environment along with the people and the ecosystem.

The US Environment Protection Agency (EPA) conducted a study in 2016 to analyze data submitted to the Toxics Release Inventory (TRI) since 1991 in an attempt to quantify the impacts of source reduction activities after implementation. The study revealed that 5 to 15 billion pounds of TRI-listed chemical releases have been prevented since 1991. It was also proposed that the source reduction projects implemented by industries that resulted in the highest reductions may be classified primarily as raw material modifications, product changes, and cleaning and degreasing changes.
Industrial hazardous waste is waste generated from industrial sectors and poses an immediate danger to the environment and the public (LaGrega et al. 2010). Illegal disposal or handling of hazardous waste can affect surface waters. In the Indian context, surface water in the form of rivers and other water bodies is used for drinking, bathing, washing, and irrigation. Therefore, the impact of contaminated water on human health and the environment is very great (Sayal et al, 2016). Surface water bodies can be contaminated or polluted by hazardous waste if run-off from hazardous waste dumps enters them, or if liquid hazardous waste is discharged directly into nearby streams that connect to larger water bodies. (Agrawal et al. 2010).

Industrial hazardous wastes are characterized in terms of toxicity (acute, chronic, and extrinsic), inflammability, reactivity, and corrosiveness (CPCB website). The main important sources of industrial hazardous wastes are mining, chemical, mechanical, pulp and paper industries, cement production facilities, wood remanufacturing facilities, etc. (Mmereki et al. 2016)

Important industrial hazardous wastes include used oil and oil contaminated materials and spent solvent. These include materials such as industrial chemical waste, industrial solvents and sludge, and waste oils (Chandrappa \& Das 2012). 


\section{Theoretical Framework}

The waste management hierarchy: The book, Silent Spring, (Carson 2002) highlighted the global problems with herbicides and pesticides and presented a view of the dangers of synthetic contaminants to the ecosystem. This book set off awareness of environmental contaminants and played a pivotal role in the framing of environmental laws. It was largely held in the 1960 s, that economic growth and development and the environment could not co-exist (Welford 1995).

The chemical manufacturing process generates waste and reduction of the amount of waste generated can be achieved by adopting waste management practices that are preferred over disposal or release of waste to the environment (Monte et al. 2009). The US Pollution Prevention Act (PPA) of 1990, provides for encouraging manufacturing facilities to first eliminate the generation or creation of chemical waste through source reduction activities (Bayrakal 2006). The waste management hierarchy is the cornerstone of waste management strategies. It consists of a five-tiered hierarchy comprising of the levels of waste prevention, reuse, recycling, recovery, and disposal. This hierarchy has been adopted by the European Union as a decision-making tool.

While prevention in terms of source reduction is the most preferred option, resource recovery, followed by recycling are the next preferred waste management methods for wastes that are generated. For waste that cannot be eliminated by recycling, burning for energy recovery is recommended followed by treatment. Disposal or release of the chemical waste into the environment is the last resort. By this hierarchy, it is envisaged that over time, manufacturers will shift from disposal or other releases toward the more preferred techniques in the waste management hierarchy that do not result in releases to the environment (Capacity Building Programme on Implementation of Waste Management Rules. 2016).

The principles of the waste management hierarchy can be adopted as the basis for any waste management plan including industrial wastewater management. García et al. (2013) seamlessly connect the Waste Management Hierarchy used in solid waste management to the scenario of industrial wastewaters in viewing organic solvents in wastewaters as resources that can be recovered and reused rather than pollutants that need to be treated and disposed of.

The levels in the waste hierarchy: The waste hierarchy (Fig. 1) establishes an order of priority for the various waste treatment options so that there is the lowest possible impact on the environment and the final waste generated is minimal (Pires \& Graça 2019)

The waste hierarchy is a waste management principle that includes the precautionary and prevention principles and provides a framework to enable a decision in waste management. This decision-making tool is useful at all levels; organizational, local as well as national (Van der Vorst et al. 1999).

Waste prevention: This level in solid waste management parlance is also called avoidance and minimization

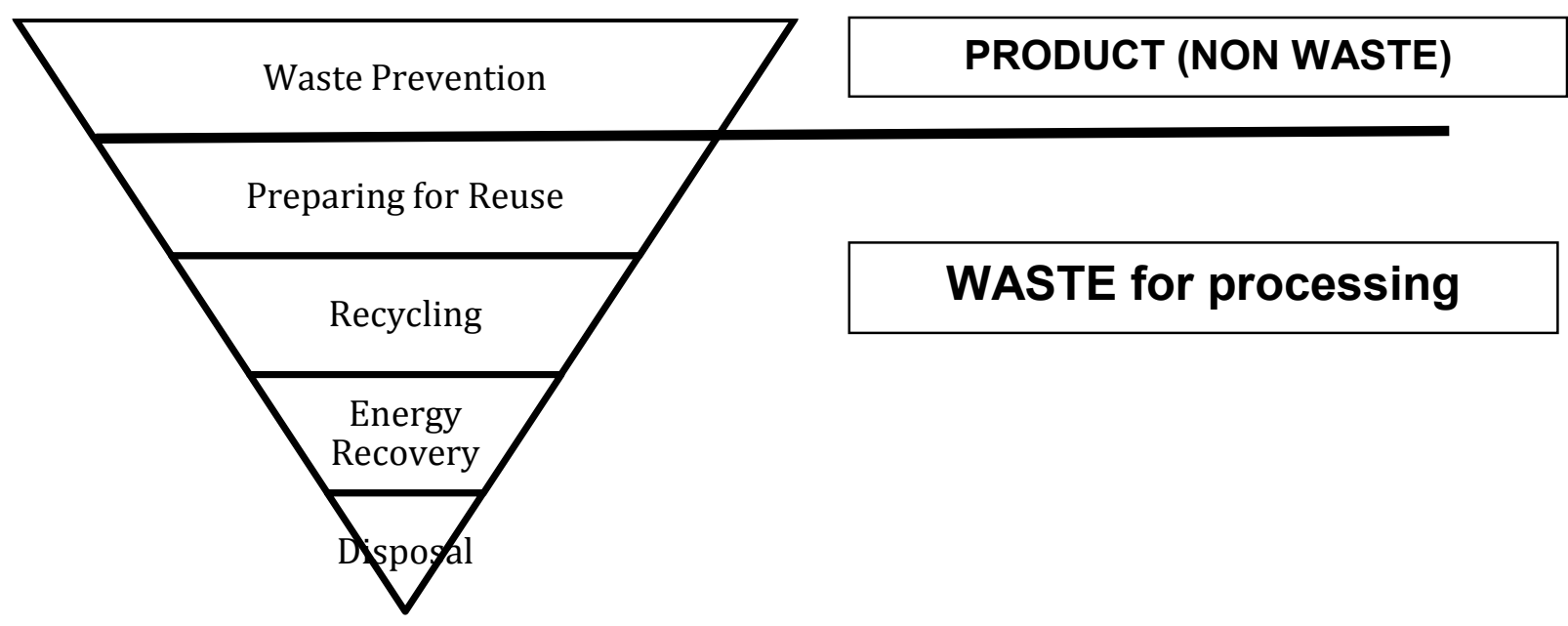

Fig. 1: The five-tiered waste hierarchy of the Waste Framework Directive 2008/98/EC

(Source: EC, 2008. DIRECTIVE 2008/98/EC of the EUROPEAN PARLIAMENT and of the COUNCIL of 19 November 2008 on Waste and Repealing Certain Directives 312, pp. 3-30.) 
where waste generation is either minimized or prevented altogether.

Preparation for re-use: This level highlights the fact that industrial wastewater is a combination of water and chemical by-products generated out of an industrial process. With appropriate technologies, these chemicals can be recovered by extraction processes for either captive use or sale and water leftover can be recycled.

Recycle level: In certain situations due to economic or technical constraints, the combinations of chemicals in the wastewater cannot be reused. In this case, the chemicals are recovered as a sludge that is sent to a landfill and the water recovered would be recycled either for industrial processes or for domestic purposes.

Energy recovery: Hazardous wastes that contain toxic chemicals with high calorific value may be incinerated in a co-processing plant replacing fossil fuels. These wastes are used as a waste to energy resource. The organic components are completely converted to carbon dioxide and water while fluorine, chlorine, and sulfur acids are neutralized by the alkaline materials within the kiln. The inorganic constituents react with the raw materials and eventually become part of the clinker matrix. Co-processing is an environmentally friendly and sustainable method of waste disposal as compared to disposal practices of landfilling and incineration because of reduced emissions and the absence of residue after the process.

Disposal: A suitable treatment is resorted to in cases where technologies of recovery or recycle are not applicable based on the characteristics of the wastewater stream generated. The treated and now benign wastewater is scientifically discharged into receiving water bodies.
In a study of the pharmaceutical industry in India, Veleva et al. (2018) extended the Waste Hierarchy to six levels, wherein preparing for reuse has been bifurcated to two relevant levels viz: recovery of chemicals for reuse and recovery of chemicals for sale. Recovered chemicals for reuse can be used for captive consumption and recovery of chemicals for sale can be sold to other manufacturers. The recovery of chemicals for resale is congruent with the concept of a circular economy. The circular economy, also known as circularity, is a regenerative idea based on the principles of reducing waste and pollution, reusing products and materials, and restoring natural systems.

\section{Technology Options}

The categorization of technology options commonly used for industrial wastewater management according to the 5 levels of the waste hierarchy is detailed in Table 1.

\section{MATERIALS AND METHODS}

The data was collected using an unstructured questionnaire and personal interviews and discussions with senior-level management executives working in the concerned chemical manufacturing firms during the year 2019. The discussions centered on the problem, the level on the Waste Hierarchy the company was at, the technology option adopted, and the impact, both quantitative and qualitative. To the extent possible, costs and benefits of the technological option adopted were sought. However, due to the confidentiality of critical data, the authors collected whatever information was forthcoming. The names of the organizations were also requested to be kept in complete confidence in exchange for the information divulged.

Table 1: Categorization of technology options commonly used for industrial wastewater management according to the 5 levels of the waste hierarchy.

\begin{tabular}{|c|c|c|c|c|}
\hline Level & $\begin{array}{l}\text { Stages of Waste Hierarchy for } \\
\text { Solid Wastes }\end{array}$ & $\begin{array}{l}\text { Stages on Waste Hierarchy for Indus- } \\
\text { trial liquid effluents }\end{array}$ & $\begin{array}{l}\text { Broad Technology options for waste- } \\
\text { water management }\end{array}$ & References \\
\hline 1 & $\begin{array}{l}\text { Waste Prevention/Avoidance/ } \\
\text { Minimization }\end{array}$ & Source reduction & $\begin{array}{l}\text { Cleaner technologies, Green chem- } \\
\text { istry }\end{array}$ & Lakavat \& Rao (2015) \\
\hline 2 & Preparing for reuse & $\begin{array}{l}\text { Resource recovery } \\
\text { - for sale (industrial ecology) } \\
\text { - for reuse }\end{array}$ & $\begin{array}{l}\text { Separation and extraction of valuable } \\
\text { chemicals }\end{array}$ & Lema \& Suarez (2017) \\
\hline 3 & Recycling & Recycling water & $\begin{array}{l}\text { Hyphenation of primary, secondary, } \\
\text { and tertiary treatment technologies, } \\
\text { Reverse Osmosis }\end{array}$ & $\begin{array}{l}\text { Gupta et al. (2012), } \\
\text { Dasgupta et al. (2015) }\end{array}$ \\
\hline 4 & Other recovery & Energy recovery & $\begin{array}{l}\text { Co-processing of chemical constitu- } \\
\text { ents of wastes in cement kilns }\end{array}$ & $\begin{array}{l}\text { Saini et al. (2017), } \\
\text { Parlikar et al. (2016) }\end{array}$ \\
\hline 5 & Disposal & Disposal after treatment & $\begin{array}{l}\text { Land-filling after treatment, Incin- } \\
\text { eration }\end{array}$ & Al Yaqout, (2003) \\
\hline
\end{tabular}




\section{Industrial Wastewater Management Strategies}

The Waste Hierarchy can serve to influence the shape of waste management strategies in organizations based on the knowledge of their waste streams, technologies available, and their economic feasibility.

The categorization of the case studies is carried out based on hierarchy levels (L) of waste management and are summarized in Table 2.

\section{RESULTS AND DISCUSSION}

\section{Case Study I: Level 1 - Source reduction is also known as Waste prevention - Reduction of waste material generated during reactor emptying operations}

\section{Company Name: XYZ Industries Limited, Mumbai, India.}

XYZ Industries Limited has a large-scale manufacturing unit located near Mumbai, India. It is a professionally managed manufacturer of organic pigments and chemicals. Organic pigments are used in paint, textiles, plastics, cosmetics, inks, and other relevant products. The company is ISO 9001:2000, IS0 14001:2004, and OHSAS 18001:2007 certified. XYZ Industries Limited has an Effluent Treatment Plant that treats the effluent which is further sent to the Common Effluent Treatment Plant (CETP). However, some part of the waste is incinerated. The solvents are reused in the manufacturing of pigments while the reactor washing water is also recycled in the process. This case study describes the effort of the company in reducing wastewater and other wastes in one of its manufacturing processes.
Process operation: Emptying of water-based viscous mass from the reactor after reaction completion.
Before
One bar gauge air pressure
is taken in a reactor after
unloading the reaction
charge.

After emptying the mass, the reactor is flushed with water.

There is solid mass scaling on the reactor wall.

The reactor has to be cleaned after 10 batch operations and around 50 $\mathrm{kg}$ solid waste material is collected from the $10 \mathrm{MT}$ reactor.
After Benefits

One bar gauge steam pressure is taken instead of air in the reactor after unloading the reaction charge.

After emptying the mass, the reactor is flushed with water.

There is less solid mass scaling on the reactor wall.

The reactor has to be cleaned after 15 batch operations and around $20 \mathrm{~kg}$ solid waste material collected from 10 MT reactor.
The reactor utilization has been extended by 36 hours considering 24 hours of reactor cleaning time every 10 days, three times in a month. Production increased by three batches viz. 30 MT per month. Waste has been reduced by $30 \mathrm{~kg}$ per cleaning and cleaning frequency reduced by 1.5 times in a month.
Information source: The information was collected during the personal discussion with the senior level management executive working in the concerned chemical manufacturing firm in 2019.

\section{Case Study II: Level 2 - Preparation for Reuse of \\ nitric acid from spent nitration mixture for nitration of chlorobenzene}
Company Name: ABC Chemicals Private Limited, Rai- gad, Maharashtra, India.

ABC Chemicals Private Limited is a medium-scale manufacturing unit located at Raigad, India, manufacturing

Table 2: Categorization of the case studies based on the levels of Waste Management Hierarchy.

\begin{tabular}{|c|c|c|}
\hline Case Study & Title of case study & Hierarchy level \\
\hline I & $\begin{array}{l}\text { Reduction of waste material generated during reactor emptying operations - Mumbai, Maharashtra } \\
\text { - India }\end{array}$ & Level 1- Source reduction \\
\hline II & $\begin{array}{l}\text { Reuse of nitric acid from spent nitration mixture for nitration of chlorobenzene - Raigad, Mahar- } \\
\text { ashtra - India }\end{array}$ & $\begin{array}{l}\text { Level } 2 \text {-Preparation for } \\
\text { reuse }\end{array}$ \\
\hline III & $\begin{array}{l}\text { Recycle of water/Reuse of proteins from the wash water of Kingfish (Surmai Fish) cleaning process } \\
\text { - Goa, India. }\end{array}$ & Level 3-Recycling of water \\
\hline IV & $\begin{array}{l}\text { Energy recovery during manufacturing of diesel from HDPE waste isolated from Municipal waste in } \\
\text { Pimpri- Chinchwad Municipal Corporation, Maharashtra, India }\end{array}$ & Level 4 -Energy recovery \\
\hline V & $\begin{array}{l}\text { Isolation of heavy metals waste from the metal plating industries - Pimpri-Chinchwad Industrial } \\
\text { Estate, Maharashtra, India. }\end{array}$ & Level 5-Treatment \\
\hline $\mathrm{V}$ & $\begin{array}{l}\text { Disposal of solids generated during manufacturing of aromatic aminophenol using sodium hydrogen } \\
\text { sulfide - Raigad, India }\end{array}$ & Level 5 - Disposal \\
\hline
\end{tabular}


and marketing chemical intermediates used for specialty chemicals and organic dyes. ABC Chemicals Pvt. Limited is a market leader in the manufacture of nitro derivatives of phenols used in dyes, cosmetics, inks, and secondary explosive applications.

The phenol nitration process is conducted safely on an industrial scale using a mixture of nitric and sulfuric acid as a nitrating agent. However, during this nitration process, some spent acid is generated which contains a few traces of un-reacted concentrated nitric acid $(\sim 0.5 \%)$. The management was concerned about the traces of nitric acid in spent acid which reduced the quality of the waste as at times the consumers of spent acid reject the spent acid as it contains traces of nitric acid which affects the production of their main product.

To remove the traces of spent nitric acid in spent acid, the R\&D team of the company devised a solution. The spent acid was washed with halo-aromatic organic solvents, which quantitatively react with nitric acid and forms the nitro-halo aromatic compound as another product. This new product can be captively consumed as one of the starting materials for yet another product.

Process operation: Washing the spent acid containing nitric acid traces with halo aromatic organic solvents.

\begin{tabular}{|c|c|c|}
\hline Before & After & Benefits \\
\hline $\begin{array}{l}\text { The spent acid gen- } \\
\text { erated as a waste } \\
\text { product of nitration } \\
\text { reaction contained } \\
\text { traces of nitric acid. }\end{array}$ & $\begin{array}{l}\text { After washing } \\
\text { with halo-aromat- } \\
\text { ic solvent the spent } \\
\text { acid was converted } \\
\text { into nitric acid-free } \\
\text { colorless spent } \\
\text { acid. }\end{array}$ & $\begin{array}{l}\text { A new compound was } \\
\text { manufactured using the } \\
\text { colorless spent acid and } \\
\text { this compound was used } \\
\text { as the starting material } \\
\text { for another product. The } \\
\text { spent acid is saleable and } \\
\text { the demand has increased } \\
\text { because it is colorless } \\
\text { and free from impurities } \\
\text { and consequently con- } \\
\text { tributes to the bottom line } \\
\text { of the company. }\end{array}$ \\
\hline
\end{tabular}

Information source: The information was collected during the personal discussion with the senior-level research staff working in the concerned chemical manufacturing firm in 2019.

\section{Case Study III: Level 3 - Recycling of Water-Recycle/ Reuse of proteins from the wash water Kingfish (Surmai Fish) process}

\section{Company Name: ABC Fisheries Private Limited, Goa, India.}

ABC Fisheries Private Limited, Goa, India is one of the largest producers of seafood in India and a market leader in the manufacture of Kingfish (Surmai Fish) in India. Each kilogram of fish typically required 8 to 10 kilograms of water thus consuming a huge quantity of freshwater for the washing process. Consequently, it generated a huge quantity of wastewater of approximately 15 to 20 lac liters per day. This wastewater from the washing process also contains proteins. The conventional approach to deal with the waste obtained from the fish washing process did not scientifically recycle or reuse the proteins as well as the water. The company has developed an integrated membrane-based solution for the recovery of valuable proteins from the wastewater from the fish washing process in an economically attractive manner. The company has successfully commissioned two commercial plants based on membrane technology for the recovery of proteins and water from wastewaters generated from the fish washing process operating at a capacity of 600 KLD and 1200 KLD respectively. The recovered proteins after further treatment could be potentially used as fish meal powder. Further, the permeate from this process which has lowered COD ( $\leq 200 \mathrm{ppm})$, TDS $(\leq 200 \mathrm{ppm})$ is being reused for washing application of fish thus recycling the water.

Process operation: Washing the spent acid containing nitric acid traces with halo aromatic organic solvents.

\begin{tabular}{|c|c|c|}
\hline Before & After & Benefits \\
\hline $\begin{array}{l}\text { Wastewater is generat- } \\
\text { ed during the kingfish } \\
\text { washing process as a } \\
\text { waste stream containing } \\
\text { proteins. } \\
\text { Due to high BOD \& COD } \\
\text { values, it could not be dis- } \\
\text { charged, recycled/reused } \\
\text { without treatment. } \\
\text { This discharge of such } \\
\text { waste streams from the } \\
\text { fish washing process } \\
\text { without treatment has cre- } \\
\text { ated many environmental } \\
\text { and ecological problems. }\end{array}$ & $\begin{array}{l}\text { After the application } \\
\text { of membrane tech- } \\
\text { nology for the recov- } \\
\text { ery of proteins from } \\
\text { the wastewater of } \\
\text { fish processing, the } \\
\text { recovered proteins } \\
\text { were converted into } \\
\text { fish meal powder as } \\
\text { well as the permeate } \\
\text { was reused for the } \\
\text { washing application. }\end{array}$ & $\begin{array}{l}\text { The use of tech- } \\
\text { nological solu- } \\
\text { tions has helped } \\
\text { the company to } \\
\text { make optimum } \\
\text { use of water re- } \\
\text { sources. By reus- } \\
\text { ing and recycling } \\
\text { proteins and wa- } \\
\text { ter, the company } \\
\text { could ascend the } \\
\text { waste hierarchy } \\
\text { compared to the } \\
\text { other firms in the } \\
\text { same industry. }\end{array}$ \\
\hline
\end{tabular}

There was an urgent need for a technological solution to this problem because of the huge volume of waste being generated on a daily basis.

Information source: The information was collected during the personal discussion with the senior-level research staff working in the organization in 2019.

Case Study IV: Level 4 - Energy recovery during the manufacture of diesel from HDPE waste isolated from municipal waste

Company Name: Pimpri- Chinchwad Municipal Corporation, Maharashtra, India

The Municipal Corporation of Pimpri-Chinchwad is locat- 
ed in Pune in Maharashtra state, India with a population of $25,00,000$ in 2011. Total waste generated in the Corporation area is approximately 1500 MT.day $^{-1}$. The total quantity of solid waste generation is $500 \mathrm{MT} \mathrm{Kg}$.day ${ }^{-1}$ of which $50 \%$ is biodegradable (dry), $25 \%$ recyclable, $15.3 \%$ green (wet), and $9.7 \%$ debris and silt. About $51 \%$ of the total solid waste collected from the entire city is biodegradable, processing the energy potential, is harnessed with anaerobic digestion, gasification, or palletization technologies. The waste is disposed of daily and dumped into the landfill site located near the Corporation. Some of the Corporation's waste lies in the form of HDPE, LDPE, PET as non-biodegradable wastes leading to pollution.

\section{Process operation: Pyrolysis of HDPE polymers to man- ufacture petroleum products and charcoal.}

Before

The waste in the form of HDPE used to be burnt in 'open to air' conditions directly in the dumping ground.

This process pollutes air, water bodies, and soil in huge quantities along with carcinogens.

The burning of HDPE has huge carbon and water footprints.
Information source: The information was collected during the personal discussion with the senior level operation staff working in the plastic pyrolysis plant in the year 2019.

\section{Case Study V: Level 5 (i) - Treatment and disposal}

\section{Industry - Isolation of heavy metals waste from the metal plating industries.}

The electroplating industry in India is mainly represented by small-scale units having distinct features such as tiny, family-owned jobber units, practices old and obsolete technologies, having unskilled or semiskilled power, located in unplanned and unauthorized areas with lack of industrial infrastructure facilities, and working in small shop areas. Most of the units function in an 'operating area of 10-25 sqm. Analytical facilities are not easily accessible to the units resulting in a lack of control on process parameters and improper documentation of production details.

Pimpri-Chinchwad Industrial Estate is located in the state of Maharashtra in India and is an industrial hub for automobile manufacturing units and other metal processing industrial units. Many parts of the automobile and die molds need metal plating to improve corrosion resistance and mechanical stress over the surface parts of the components. To improve performances and durability, the machine parts have to be coated with various plating materials like hard-chrome, copper, zinc plating, etc.

Electroplating wastewater contains highly toxic cyanide, cyanide complexes, and metal ions that make treatment a complex problem. As the electroplating industries are located

Table 3: Qualitative and quantitative impact of the Waste Management Hierarchy on manufacturing organizations.

\begin{tabular}{|c|c|c|c|}
\hline $\begin{array}{l}\text { Level on Waste } \\
\text { Hierarchy }\end{array}$ & Environmental & Social & Economic \\
\hline Waste Prevention & Reduces uptake of raw materials & Green credentials with industry peers & $\begin{array}{l}\text { Reduction in waste management costs } \\
\text { Waste valorization adds to the bottom line }\end{array}$ \\
\hline $\begin{array}{l}\text { Preparation for } \\
\text { reuse }\end{array}$ & $\begin{array}{l}\text { Impacts material processing by saving } \\
\text { natural resources } \\
\text { Reduces waste volumes }\end{array}$ & Preservation of virgin raw materials & $\begin{array}{l}\text { Reduction in material costs } \\
\text { Control over material input quality }\end{array}$ \\
\hline $\begin{array}{l}\text { Recycling of } \\
\text { Water }\end{array}$ & $\begin{array}{l}\text { Reduction in water withdrawals } \\
\text { Less competition with other water } \\
\text { users }\end{array}$ & $\begin{array}{l}\text { Sharing of water with local communities } \\
\text { for agriculture/domestic uses. }\end{array}$ & $\begin{array}{l}\text { Reduction in water expenses } \\
\text { Control over water quality }\end{array}$ \\
\hline Energy Recovery & -Destruction of hazardous waste & $\begin{array}{l}\text { - Sharing of energy generated with local } \\
\text { communities }\end{array}$ & $\begin{array}{l}\text {-Reduction in use of non-renewable fossi } \\
\text { fuels } \\
\text { - Reduction in energy costs }\end{array}$ \\
\hline $\begin{array}{l}\text { Treatment and } \\
\text { Disposal }\end{array}$ & - Reduction of sludge to landfill & $\begin{array}{l}\text { - Opposition from communities for new or } \\
\text { expansion of landfills } \\
\text { - Loss of aesthetic appeal of the local } \\
\text { environment. } \\
\text { - Safe containment of waste }\end{array}$ & $\begin{array}{l}\text {-Costs of transportation, fuel, manpower, } \\
\text { regulatory and compliance costs }\end{array}$ \\
\hline
\end{tabular}


in small and unorganized sectors in India, the problem becomes more grave. Due to the lack of technology, automation, and process control, the effluent exhibits variable characteristics. It is observed that the effluent has high Biological Oxygen Demand (BOD), Chemical Oxygen Demand (COD), Suspended Solid (SS), Dissolved Solid (DS), Total Solids (TS), Color, and Turbidity and there is depletion of oxygen. The electroplating industry consumes and discharges large volumes of wastewater. The use of various chemicals and metal salts creates pollution-related problems. The major contributor to pollution is rinsed water, spray losses, and solution dumping and leakages. Valuable metals and cyanide along with different chemicals used are lost in wastewater. The loss varies between $2-20 \%$ of the chemicals used.

\section{Process operation: Treatment of effluents with sodium sulfide}

\begin{tabular}{|c|c|c|}
\hline Before & After & Benefits \\
\hline $\begin{array}{l}\text { The effluent generat- } \\
\text { ed as a waste product } \\
\text { of metal electroplat- } \\
\text { ing reaction contains } \\
\text { heavy metal ions such } \\
\text { as nickel, chromium, } \\
\text { zinc, lead, silver, cad- } \\
\text { mium, mercury, etc. } \\
\text { as well as cyanides, } \\
\text { hydrogen sulfides, am- } \\
\text { monia, highly toxic } \\
\text { chloramines. }\end{array}$ & $\begin{array}{l}\text { After treating the } \\
\text { wastewater with } \\
\text { sodium sulfide or } \\
\text { sodium hydroxide, } \\
\text { these heavy metal } \\
\text { salts produce cor- } \\
\text { responding sulfides } \\
\text { or hydroxides and } \\
\text { precipitates as metal } \\
\text { sulfides and metal } \\
\text { hydroxides respec- } \\
\text { tively. }\end{array}$ & $\begin{array}{l}\text { The treated stream } \\
\text { of the effluents is } \\
\text { free from heavy } \\
\text { metal waste. } \\
\text { The heavy metal } \\
\text { sulfides or hydrox- } \\
\text { ides can be easily } \\
\text { separated and a few } \\
\text { of them (e.g. copper } \\
\text { and zinc) are used } \\
\text { as micronutrients } \\
\text { sources in agro- }\end{array}$ \\
\hline $\begin{array}{l}\text { Electroplating wastewa- } \\
\text { ter has high BOD/COD, } \\
\text { SS, DS, TS, Turbidity, } \\
\text { color, and depletion of } \\
\text { oxygen along with met- }\end{array}$ & $\begin{array}{l}\text { This precipitate set- } \\
\text { tles at the bottom of } \\
\text { the tank and can be } \\
\text { easily removed from } \\
\text { the effluent stream. }\end{array}$ & $\begin{array}{l}\text { chemicals. } \\
\text { A heavy reduction } \\
\text { in COD, BOD, TS, } \\
\text { and turbidity of the } \\
\text { effluent stream is } \\
\text { achieved. }\end{array}$ \\
\hline
\end{tabular}

Information source: The information was collected during the personal discussion with the senior level operation staff working in the plant in the year 2019.

\section{Case Study V: Level 5 (ii) - Treatment and disposal - Disposal of solids generated during manufacturing of aromatic aminophenol using sodium hydrogen sulfide}

\section{Company Name - QPR Chemicals Private Limited, Raigad, India}

QPR Chemicals has a medium-scale manufacturing unit located at Raigad, India producing dye intermediates. The dye molecules have various organic functional groups such as $-\mathrm{NO}_{2},-\mathrm{COOH}, \mathrm{Ar}-\mathrm{OH}$, etc. Sodium hydrogen sulfide is one of the selective chemical reagents for the stoichiometric reduction of the nitro group to an amino group in the presence of the phenolic group.
Selective reduction of nitrophenols to produce aminophenol using sodium hydrogen sulfide produces a colored aqueous stream with a very high content of the mixture of sodium thiosulphate, sodium thiosulphite, and other sodium salts. These salts contain about 9-10\% TDS and TSS content.

\section{Process operation: Application of multiple-effect evap- oration (MEE) plant with RVPD (Rotary Vapor Phase Drier)}

Before
The effluent gener-
ated in this process
contains a high con-
centration of sodium
salts as a toxic waste
product.
This effluent has
high BOD/COD, SS,
DS, TS, Turbidity,
Color (red)

After

The application of MEE and RVPD produces low effluent and liquid effluent can be gradually reduced.

The dried solid waste is dispatched for land-filling to Mumbai Solid Waste Management Corporation.

\section{Benefits}

The liquid waste with high COD and colored stream has been prevented from occurring which subsequently decreased the amount of effluent generated from the plant.

This process decreased the workload on Effluent Treatment Plant.
Information source: The information was collected during the personal discussion with the senior level operation staff working in the plant in the year 2019.

\section{CONCLUSION}

The Waste Management Hierarchy has been used in guiding technology options towards higher-order levels on the hierarchy. Initially used in the sphere of Solid Waste, the Waste Management Hierarchy can be translated to be applied to industrial wastewater streams.

The industrial waste management hierarchy was discussed in detail. Five environment management strategies were studied from passive through reactive to proactive approaches and further supported by case studies. Industrialization causes so many problems threatening the planet earth because of wastes, emissions, and pollution. The waste management strategies have progressed from disposal to treatment, recycling, reuse, and reduction at the source itself. In some cases, there is an opportunity to integrate strategy across more than one level of the hierarchy as seen in Case study III where recycling of water and reuse of the waste product are combined. These approaches of waste management although better than disposal are not enough to create a clean environment. To overcome these problems, a cleaner production strategy is one of the options to bring about green growth and ensure sustainable development, where the environment and society are as important as the economy. 
Therefore, countries of the world, whether developed or developing, should invest in cleaner production. The various strategies used for various types of effluent-related problems were identified and each one has been solved using different waste management strategies through the decision-making tool as propounded through the Waste Management Hierarchy.

The impact of the Waste Management Hierarchy on the adoption of technology options can be summarized on the three pillars of sustainability as shown in Table 3.

\section{ACKNOWLEDGEMENTS}

The authors are thankful to all the organizations that shared the necessary information sought for the sole purpose of this academic work.

\section{REFERENCES}

Agrawal, A., Pandey, R.S. and Sharma, B. 2010. Water pollution with special reference to pesticide contamination in India. J. Water Resour. Prot., 2(5): 432-448.

Al Yaqout, A.F. 2003. Assessment and analysis of industrial liquid waste and sludge disposal at unlined landfill sites in the arid climate. Waste Manag., 23(9), 817-824.

Bayrakal, S. 2006. The US pollution prevention act: A policy implementation analysis. Soc. Sci. J., 43(1): 127-145.

Capacity Building Programme on Implementation of Waste Management Rules. 2016. Your Guide For Hazardous \& Other Wastes, https://www. npcindia.gov.in/NPC/Files/delhiOFC/EM/Hazardous-waste-management-rules-2016.pdf. (accessed on $5^{\text {th }}$ June 2020)

Carson, R., 2002. Silent Spring. Houghton Mifflin Harcourt, Boston, MA, USA.

Central Pollution Control Board (CPCB). n.d. Ministry of Environment, Forest and Climate Change, Government of India. https://cpcb.nic.in/ water-pollution/ (accessed on $5^{\text {th }}$ June 2020)

Chandrappa, R. and Das, D.B. 2012. Wastes from Industrial and Commercial Activities. In Chandrappa, R. and Das, D.B. (eds.), Solid Waste Management, Springer, Berlin, Heidelberg, pp. 217-247.

Dasgupta, J., Sikder, J., Chakraborty, S., Curcio, S. and Drioli, E. 2015.
Remediation of textile effluents by membrane-based treatment techniques: a state of the art review. J, Environ. Manag., 147, 55-72.

García, V., Pongrácz, E., Phillips, P.S., Keiski, R. L. 2013. From waste treatment to resource efficiency in the chemical industry: Recovery of organic solvents from waters containing electrolytes by pervaporation. J. Cleaner Prod., 39: 146-153.

Gupta, V.K., Ali, I., Saleh, T.A., Nayak, A. and Agarwal, S. 2012. Chemical treatment technologies for waste-water recycling - an overview. RSC Adv., 2: 6380-6388.

LaGrega, M. D., Buckingham, P. L. and Evans, J. C. 2010. Hazardous Waste Management. Waveland Press, Long Grove, US.

Lakavat, M. and Rao, L.N, Innovative control measures of water: A study on green chemistry. Amer. J. Mater. Sci., 5(3C): 169-174.

Lema, J.M. and Suarez, S. 2017. Innovative wastewater treatment \& resource recovery technologies: Impacts on energy, economy, and environment. Water Intell. Online, 16: 81-97. https://doi. org/10.2166/9781780407876.

Mmereki, D, Adrew, B, Liu H. and Baizhan, L. 2016. The management of hazardous waste in developing countries. Manag. Hazard. Wastes, 2016: 39.

Monte, M., Concepcion, E., Fuente, A., Blanco. and Carlos, N. 2009. Waste management from pulp and paper production in the European Union. Waste Manag., 29(1): 293-308.

Parlikar, U., Bundela, P.S., Baidya, R., Ghosh. S.K. and Ghosh, S.K. 2016. Effect of variation in the chemical constituents of wastes on the co-processing performance of the cement kilns, Procedia Environ. Sci., 35: 506-512. https://doi.org/10.1016/j.proenv.2016.07.035.

Pires, A. and Graça, M. 2019. Waste hierarchy index for circular economy in waste management. Waste Manag., 95: 298-305.

Saini, S., Bamniya, B. R., Ramakrishna, G. V. and Kumawat, D. M. 2017. Study of pollution load in the environment during coprocessing of solid waste (carbon black) in cement rotary kiln. Pollut. Res., 36(3):645-650.

Sayal, A., Amjad, S., Bilal, M., Pervez, A., Mahmood, Q. and Afridi, M.A. 2016. Industrial water contamination and health impacts: An economic perspective. Pol J Environ Stud., 25(2). 60-72

Van Der Vorst, R., Grafé-Buckens, A. and Sheate, W.R. 1999. A systemic framework for environmental decision making. J. Environ. Assess. Policy Manag., 1(1): 1-26.

Veleva, V.R., Cue Jr, B.W., Todorova, S., Thakor, H., Mehta, N.H and Padia, K.B. 2018 Benchmarking green chemistry adoption by the Indian pharmaceutical supply chain. Green Chem. Lett. Rev., 11:4, 439-456.

Welford, R. 1995. Environmental Strategy and Sustainable Development: The corporate challenge for the twenty-first century. 6th edition. Routledge, London 